\title{
Belgeo
}

Revue belge de géographie

1 | 2007

The advanced service sectors in European urban regions

\section{Advanced services and city globalization on the Eastern fringe of Europe}

Services avancés et mondialisation urbaine dans la frange orientale de l'Europe

\section{Lise Bourdeau-Lepage}

\section{(2) OpenEdition}

\section{Journals}

Electronic version

URL: http://journals.openedition.org/belgeo/11703

DOI: 10.4000/belgeo.11703

ISSN: 2294-9135

Publisher:

National Committee of Geography of Belgium, Société Royale Belge de Géographie

\section{Printed version}

Date of publication: 1 January 2007

Number of pages: 133-146

ISSN: 1377-2368

\section{Electronic reference}

Lise Bourdeau-Lepage, "Advanced services and city globalization on the Eastern fringe of Europe », Belgeo [Online], 1 | 2007, Online since 09 December 2013, connection on 19 April 2019. URL : http:// journals.openedition.org/belgeo/11703; DOI : 10.4000/belgeo.11703

This text was automatically generated on 19 April 2019

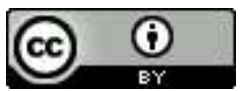

Belgeo est mis à disposition selon les termes de la licence Creative Commons Attribution 4.0 International. 


\title{
Advanced services and city globalization on the Eastern fringe of Europe
}

Services avancés et mondialisation urbaine dans la frange orientale de l'Europe

\author{
Lise Bourdeau-Lepage
}

This study is part of a research program on "The development of high-order services and spatial change in the ECEEC", carried out in the LEG with the support of Burgundy Regional Council and the French Ministry of Research.

\section{Introduction}

1 We live in an age where the economy is dominated by cities. Huriot and Thisse (2000, xiv) invite us to "reconsider the role of cities in economic life" and suggest that "cities will be important actors on the economic stage of the future". The context of the post-industrial economy inevitably assigns a primary role to cities and especially to global cities. A global city may be defined as a center of coordination of complex economic activities at a global scale (Bourdeau-Lepage \& Huriot, 2005b). The literature offers near-synonymous terms such as world cities (Hall, 1966; Friedman, 1986; Knox \& Taylor, 1995; Taylor, 2003), international cities, metropolises (Hoover \& Vernon 1962), or business metropolises (Bourdeau-Lepage \& Huriot, 2005b). The process by which a city emerges as a global city is termed "city globalization". It refers more or less to what the French literature calls metropolization (Lacour \& Puissant, 1999).

2 Global cities are both the privileged places of advanced services and the strategic nodes of global networks. Because of their specialization and their need for mutual contacts, advanced services are mostly concentrated in the CBDs of global cities, so their presence is a natural and decisive factor of city globalization. Through their global coordination functions, advanced services connect global cities to one another, so forming global 
networks (Castells, 1996). Consequently, global cities are interacting cities and global interactions are another key factor of city globalization.

Thus, only certain cities, global cities, concentrate global coordination functions (Sassen, 2001). These cities are mainly located in Northern developed countries and in some Asian-Pacific countries (Bourdeau-Lepage \& Huriot, 2005a; Dogan, 2004; Sassen, 2002; Taylor, 2003). City globalization is a geographically selective process affecting just a few cities in countries which are major players in the globalized world economy. This process may take an original turn in the large cities of East Central and Eastern European Countries (ECEEC) since their opening-up to the global economy.

These countries are transition economies which all abandoned the central planning system about 15 years ago. This transition process entails not only adopting the rules of the market, but also adapting to the global character of the emerging post-industrial economy and thus acquiring the capacity to participate in global networks. Consequently, since the 1990s, the ECEEC capitals have faced the double challenge of the market (the transition process) and of integration in the world economy (the globalization process), which supposes a sufficient development of coordination functions and thus of advanced services concentrated in these cities (city globalization). These major cities are changing rapidly. New market economies generate increasing external interactions requiring more coordination and new forms of coordination, and therefore more advanced services which contribute to transforming the economy of major cities (Bourdeau-Lepage, 2004).

This paper aims at appraising the capacity of ECEEC capitals to join the global city network by emphasizing the role of advanced services and of global interactions.

6 Five cities - Bucharest, Budapest, Prague, Sofia, and Warsaw - are studied here for several reasons. They all have more than one million inhabitants, which is often considered as the standard minimum size for a global city (Angotti, 1993). They include capital cities of countries involved in the latest round of European enlargement in 2004 (the Czech Republic, Hungary and Poland), and of countries waiting to join at a later stage (Bulgaria and Romania). These countries are in very unequal situations in terms of their GDP as well as in terms of their historical background or geographical situation. In such unequal environments, these cities probably do not have the same chances of joining the global network of world cities.

Before coming to the core of this investigation, it is useful to provide the theoretical background. Then, the proportions of advanced services in employment and the presence of multinational firms in the five cities are evaluated and compared. This reveals significant disparities, which are reinforced by the unequal insertion of these cities in the interaction networks. Finally, clearly contrasted globalization perspectives are pointed out.

\section{Analytical background: global cities and advanced services}

The emergence of the post-industrial economy and the associated growing need for coordination are bringing about far-reaching changes and considerably extending the coordination functions and the related advanced services, giving rise to a global cities network. 


\section{The emerging post-industrial economy...}

Global cities are centers of coordination and nodes of global interaction networks (eg. Beaverstock et alii, 1999; Sassen, 1994 et 1999; Reed, 1981; Bourdeau-Lepage \& Huriot, 2005b). Now, the post-industrial economy generates new and increasing coordination needs. Coordination functions and their intensive use of information are permanent urban features (Hohenberg \& Lees, 1995), but their extension and their implementation are entirely new (eg Castells, 1996).

10 Three major characteristics of the post-industrial economy underlie the increasing need for coordination.

11 In the post-industrial economy, production is increasingly intangible, i.e. services are more and more at the forefront.

Production is ever more differentiated and personalized, in manufactured goods and even more so in services, and this is tied in with the development of the preference for variety of consumers.

13 A large part of production is clearly globalized, i.e. its management and organization as well as its supporting services are integrated at the world scale (Sykora, 1995). Globalization has benefited from the reduction in transport costs which allows production to be delocalized to remote countries with low labor costs and promotes the emergence of a new division of labor. It has also been made easier by the deregulation of markets and by the information revolution (Sassen, 2002).

\section{...entails new needs for coordination...}

14 The post-industrial economy is global and operates in real time at a planetary scale (Castells, 1996). Such a production system generates complexity and uncertainty and consequently calls for new specific needs for coordination.

15 First of all, the extreme diversification and specialization of the service sector, the keyactivity of the post-industrial economy, necessitates a co-production relationship based on cooperation and information exchanges between seller and buyer. Secondly, the world-wide dispersion of production and/or of customers increases the need for complex information and for specialized advanced services. Actually, headquarters, controlling plants or other establishments operating in a number of remote countries, require knowledge of different cultures and different legal systems and call for a high level of organization and control. Thus, the adaptation of supply to demand, the drawing-up and performance of agreements as well as the complexity of economic interactions and the expansion of markets in a globalized world give rise to important new needs for coordination.

\section{...satisfied by advanced services concentrated in global cities...}

Coordination, defined as the set of interactions between economic agents brought into play with the aim of efficiently organizing production, exchange and consumption, gives rise to transaction costs (Bourdeau-Lepage \& Huriot, 2005b). Thus, increasing coordination needs lead to higher transaction costs incurred in the search for partners, and in the negotiation, drawing-up, enforcement and control of agreements (North, 
1990). The rise of advanced services makes it possible to manage complex coordination more efficiently and to limit the increase in transaction costs (Behrens K., 2003).

Indeed, global advanced services are activities devoted to the coordination of complex economic activities at a large spatial scale. They include the highest level of financial and producer services, of research and development, of planning, of business administration and, in general, of activities specialized in decision-making and control (Sassen, 2002). Since these activities are very specialized, they operate with increasing returns and are more efficient if they supply a large market. Because of this specialization, they are complementary to each other and have to collaborate in order to solve coordination problems. In addition, they make intensive use of highly specialized skills which can be found more readily in a large city where a lot of specialized services are already located. Finally, their need for complex and personalized (tacit) information exchanges implies face-to-face contacts (Gehrig, 2000; Sassen 2001).

Thus, these activities are selectively concentrated in global cities where they find large markets and where face-to-face contacts are easier. (eg Bourdeau-Lepage \& Huriot, 2005b).

\section{...interconnected in global networks}

The concentration of global coordination functions represents only one side of the global city. On the other side, global cities are organized in global networks where major connections are made of information exchanges by the new communication technologies and of business trips using rapid means of transport like planes or fast trains. The new communication technologies have a strategic role, directly by permitting efficient longdistance circulation of enormous amounts of standardized (codified) information at a very low marginal cost, and indirectly by giving rise to and preparing business trips, the aim of which is to realize long-distance exchanges of tacit information.

The interplay between the agglomeration side, depending on proximity interactions, and the network side, depending on long-distance interactions, determines the form of the global city network. Three features can be emphasized.

21 First, agglomeration of high-order functions is favored by the low level of any-distance communication costs by the new technologies. It is a well-known result in agglomeration economics that all things being equal, low transport costs make agglomeration more probable (Fujita \& Thisse, 2002). Along the same lines, it can be argued that concentration in a small number of global cities, in order to benefit from local externalities and increasing returns, is favored by low communication costs between these cities and the dispersed economic activity they control.

22 Second, the use of communication technologies requires substantial information infrastructures and therefore entails high fixed costs. These functions are therefore located in large cities where informational infrastructures are well developed. This generates a cumulative process which gives the prime role of coordination to global cities in the post-industrial context.

Third, the preceding agglomeration forces are impeded by dispersion forces without which there would be a single world city controlling the world economy. Apart from the classical limits of city growth imposed by rising land prices, increasing commuting costs and environmental damage, one should not overlook the effect of the localized character 
of tacit information (Gehrig, 2000) relative to the culture, the formal and informal economic practices and the preferences in local economies. For example, this helps to explain the existence and the dispersion of multiple financial centers around the world.

The interplay between the agglomeration side and the network side produces the conditions for a cumulative process reinforcing city globalization. Thus, the takeoff can be crucial in the city globalization process. This suggests that history matters in the formation of global cities.

Consequently, global cities concentrate coordination functions and interact with one another by business trips and the new communication technologies, so forming global city networks.

On this basis, a set of criteria is used to evaluate city globalization. The focus here is on production structures and on the presence of advanced services in ECEEC capitals, as well as on certain aspects of their long-range interactions.

\section{The unequal expansion of advanced services}

The concentration of advanced services is the core of city globalization. It will be investigated first by comparing the employment structures of the five chosen cities, especially the proportions of advanced services in their employment structures, which reveals meaningful inequalities; second, by reporting the presence of firms specialized in "advanced" producer services, which reinforces the preceding diagnosis.

\section{Differentiated employment structures}

Direct comparison between the five cities can be made on the basis of what can be called intercity location quotients (LQ). For a given sector, the intercity LQ is the ratio of the share of that sector in the city employment to the average share of that sector in the five capital cities (see appendix). This ratio permits direct comparisons between the employment structures of the five cities, regardless of their hinterlands, from the sole point of view of their relative ability to engage in a city globalization process.

Emphasis is put on advanced services, which are indirectly grasped through the sectors "financial intermediation" and "real estate, renting and business activities". It is wellknown that they include household services as well as some low-order producer services. However a more in-depth analysis is hardly possible since the breakdown into sub-sectors of advanced services is limited to these two sectors.

It appears that the relative specializations of the five cities in financial intermediation and in real estate \& business activities differ noticeably (see table 1). The relative specialization in financial intermediation is more marked in Prague and above all in Warsaw, while Sofia and Bucharest are less specialized than the average. Differences of specializations in real estate \& business activities are much less significant, the location quotients varying only from 0.9 to 1.2 . Warsaw is in the first place among the five cities for the concentration of this sector, even if it is relatively less specialized in real estate \& business activities (intercity LQ of 1.2) than in financial intermediation (intercity LQ of 1.7). 
Table 1. Intercity Location quotients (2001).

\begin{tabular}{|c|c|c|c|c|c|c|}
\hline \multirow[b]{2}{*}{ Branches (NACE 1 rev. 1) } & \multirow{2}{*}{$\begin{array}{c}\text { Average } \\
5 \text { cities } \\
\text { in } \%\end{array}$} & \multicolumn{5}{|c|}{ Interclty LQ } \\
\hline & & BUCHAREST & BUDAPEST & PRAGUE & $\begin{array}{l}\text { SOFIA } \\
\text { mun }\end{array}$ & WARSAW \\
\hline Agriculture $^{1}(A+B)$ & 0.6 & 1.5 & 0.8 & 1.2 & 0.8 & 0.7 \\
\hline Manufacturing (D) & 16.4 & 1.5 & 0.9 & 0.6 & 1.1 & 0.9 \\
\hline $\begin{array}{l}\text { Electricity, gas, water supply, mining \& } \\
\text { quarrying (C+E) }\end{array}$ & 2.1 & 1.4 & 0.6 & 1.1 & 1.0 & 0.9 \\
\hline Construction (F) & 6.8 & 1.1 & 0.6 & 1.4 & 0.9 & 1.0 \\
\hline Trade and repair (G) & 15.9 & 1.1 & 0.8 & 1.0 & 1.1 & 1.0 \\
\hline Hotels and restaurants $(\mathrm{H})$ & 2.7 & 0.5 & 1.2 & 1.5 & 1.1 & 0.8 \\
\hline Transport, storage, communication (I) & 9.6 & 1.0 & 1.0 & 1.0 & 1.1 & 0.9 \\
\hline Financial intermediation $(\mathrm{J})$ & 4.5 & 0.6 & 0.8 & 1.1 & 0.7 & 1.7 \\
\hline $\begin{array}{l}\text { Real estate, renting \& business activities } \\
\text { (K) }\end{array}$ & 12.8 & 0.9 & 0.9 & 1.0 & 1.1 & 1.2 \\
\hline $\begin{array}{l}\text { Pub administration, defense, social } \\
\text { security (L) }\end{array}$ & 9.0 & 0.4 & 2.2 & 0.8 & 0.6 & 0.8 \\
\hline Education (M) & 7.4 & 0.9 & 1.1 & 0.9 & 1.1 & 1.0 \\
\hline Health \& social work (N) & 7.1 & 0.7 & 1.2 & 1.1 & 0.9 & 1.1 \\
\hline Personal \& household services ${ }^{2}(\mathrm{O}+\mathrm{P}+\mathrm{Q})$ & 5.2 & 1.1 & 0.8 & 1.5 & 1.0 & 0.8 \\
\hline Total & 100.0 & 1.0 & 1.0 & 1.0 & 1.0 & 1.0 \\
\hline \multicolumn{7}{|c|}{$\begin{array}{l}\text { in } 2000 . \\
1 \text { Agriculture includes: farming, hunting, forestry; fishing. } \\
2 \text { Personal \& household services include: other community, social and personal service activities; activities of } \\
\text { household. } \\
\text { Sources: calculated from INSSE (2003); KSHBPMI (2002); Czech Statistical Office (2003a and b); Municipality of } \\
\text { Sofia (2003); BULSTAT (2003), EUROSTAT (2003); USW (2003) and GUS (2002). }\end{array}$} \\
\hline
\end{tabular}

It is noteworthy that of the five cities, Prague has the highest specialization in hotels and restaurants (table 1: intercity location quotient equal to 1.5). Prague is clearly attuned to tourism. For the same sector, Bucharest displays the opposite characteristics, with a very low intercity location quotient of 0.5 : in this domain, Bucharest remains well behind the other cities.

Regarding the manufacturing sector, it will be recalled that one of the major features of transition economies is their rapid de-industrialization (see for additional information, Bourdeau-Lepage, 2006). Nevertheless, in Bucharest, manufacturing still makes up $24.3 \%$ of the city's employment, which is a very much higher proportion than in the other cities, even in Sofia, which is still highly industrialized (see table 2). Thus, with respective LQs of 1.5 and of 1.1, Bucharest and Sofia are relatively more specialized in manufacturing than Prague, Budapest and Warsaw.

Consequently, two results are suggested. First, differences in the employment structures of the five cities are relatively small, especially for advanced services, suggesting that they are pulled by a common global force. Second, these differences are sufficient to determine a significant ranking in which Warsaw, Prague and Budapest display more favorable structures than Bucharest and Sofia in terms of city globalization. 
Table 2. Percentages of employment in manufacturing and advanced services.

\begin{tabular}{|c|c|c|c|c|c|c|c|c|c|c|}
\hline \multirow{2}{*}{$\%$ of total employment } & \multicolumn{2}{|c|}{ BUCHAREST } & \multicolumn{2}{|c|}{ BUDAPEST } & \multicolumn{2}{|c|}{ PRAGUE } & \multicolumn{2}{|c|}{ SOFIA mun. } & \multicolumn{2}{|c|}{ WARSAW } \\
\hline & $1994^{1}$ & 2001 & 1995 & 2001 & 1994 & 2001 & $1996^{-1}$ & 2000 & $1994^{+}$ & 2001 \\
\hline Manufacturing & - & 24.3 & 18.1 & 14.4 & 14.8 & 10.5 & - & 17.3 & 25.6 & 14.8 \\
\hline Financial intermediation & - & 2.8 & 3.5 & 3.4 & 3.2 & 4.9 & - & 3.2 & 6.0 & 7.8 \\
\hline $\begin{array}{r}\text { Real estate, renting and } \\
\text { business activities }\end{array}$ & - & 11.5 & 6.5 & 11.2 & 12.7 & 12.8 & - & 13.6 & 14.9 & 15.0 \\
\hline Advanced services ${ }^{2}$ & - & 14.3 & 11.0 & 14.6 & 15.9 & 17.7 & - & 16.8 & 20.9 & 22.8 \\
\hline
\end{tabular}

\section{Advanced services firms and the ranking of global cities}

The presence of international firms specialized in advanced services is also a major criterion of city globalization. It can be used to evaluate the global dimension of a city's coordination functions. This evaluation refers to a study conducted by the Globalization and World Cities network (GaWC).

An inventory of 123 world cities (Beaverstock et alii, 1999) is based on the presence of four "advanced" producer services: accountancy, advertising, banking/finance, and law. For each service, cities are classified in three groups: prime centers ( 3 points), major centers ( 2 points), and minor centers (1 point), depending on the degree of presence of the largest international firms in this activity. The four classifications obtained are combined by giving each city a grade from 1 to 12 , equal to the sum of the points obtained. The resulting roster clusters the cities in four categories by decreasing grade: 10 "Alpha World Cities" (grades 12 to 10), 10 "Beta World Cities" (grade 9 to 7), 35 "Gamma World Cities" (grades 6 to 4), and 67 "Evidence of World City Formation" (grades 3 to 1). The global evaluation of the five ECEEC capitals is given by table 3. 
Table 3. The inventory of world cities.

\begin{tabular}{|c|c|c|c|c|c|c|c|}
\hline $\begin{array}{c}\text { Activity/ } \\
\text { City }\end{array}$ & Accountancy & Advertising & Banking & $\begin{array}{c}\text { Legal } \\
\text { services }\end{array}$ & $\begin{array}{c}\text { General } \\
\text { grade }\end{array}$ & Category & $\begin{array}{c}\text { Comparable } \\
\text { cities }\end{array}$ \\
\hline Bucharest & n.g. * & minor & n.g. & minor & 2 & $\begin{array}{c}\text { "Some" } \\
\text { evidence } \\
\text { of world } \\
\text { city } \\
\text { formation }\end{array}$ & $\begin{array}{c}\text { Lisbon } \\
\text { Rotterdam } \\
\text { Stuttgart }\end{array}$ \\
\hline Budapest & n.g. & minor & minor & major & 4 & gamma & $\begin{array}{c}\text { Barcelona } \\
\text { Berlin } \\
\text { Munich } \\
\end{array}$ \\
\hline Prague & n.g. & major & major & major & 6 & gamma & $\begin{array}{c}\text { Amsterdam } \\
\text { Düsseldorf } \\
\text { Geneva }\end{array}$ \\
\hline Sofia & n.g. & n.g. & n.g. & n.g. & & & \\
\hline Warsaw & n.g. & minor & major & major & 5 & gamma & $\begin{array}{c}\text { Rome } \\
\text { Stockholm }\end{array}$ \\
\hline
\end{tabular}

* non graded.

Source: Beaverstock et alii, (1999)

Prague scores well (major center) for advertising, banking and legal services, and Warsaw for banking and legal services. The ranking is consistent with expectations and confirms the preceding evaluations. Prague, Warsaw and Budapest are major centers in at least one category of advanced services. They are gamma world cities. Prague is the most complete while Sofia is non-graded.

Obviously, this evaluation records only the presence of major world firms. But such firms are the most able to develop global interactions and to generate city globalization where they have a significant presence.

\section{Expected global Interactions}

The concentration of advanced services in global cities is only one side of the city globalization process. The other side is the insertion in the world network of interacting cities. Considering that intercity flows, and particularly immaterial flows, can hardly be directly evaluated (eg Taylor, 1999), only indirect indicators will be used.

First of all, this insertion is influenced by the relative location of each city in the world city system, which affects its potential for interaction. Here, the analysis is restricted to the European network.

Secondly, integration is achieved through a set of connections which permit global interactions. Connections between advanced activities can be established in terms of codified information flows and of executive trips, and they result in part from the simultaneous presence of advanced service firms in several cities. Because codified information flows are difficult to grasp, only the second and the third aspects of these interactions are examined. 


\section{Location, interactions and attractiveness}

41 City globalization is closely linked to interaction networks. Now, the relative location of cities helps to explain the intensity of their interactions. Even if interactions by the new information technologies are partly independent of location, distances still largely influence trade and complex interactions between advanced services. The interaction potential of each city relies partly on its position relative to other cities.

The evaluation of such positions may take different forms related to the analysis of centrality, accessibility and spatial potentials (Huriot \& Perreur, 1997). Two approaches are proposed, the formulation of which is given in the technical appendix. The "relative interaction potential" of European capitals is based on the theory of gravitation. For each city, it depends positively on that city's population and on the ratios population to distance from that city, calculated for every other capitals. The "relative attractiveness" of a possible global city is calculated for each of the five ECEEC capitals. It varies positively with the weight of advanced services in this city (evaluated by the level of employment in sectors $\mathrm{J}$ and $\mathrm{K}$ ) and negatively with the distance to the other 26 European capitals. The results and the rankings obtained appear in table 4 . They prompt the following statements.

Table 4. Interaction potentials and attractiveness.

\begin{tabular}{|c|c|c|c|c|}
\hline City I & $\mid \begin{array}{ll}1 & \\
& I P_{i}^{1}\end{array}$ & Rank & $R A_{i} \operatorname{HOS}^{2}$ & Rank \\
\hline London & 1.00 & 1 & & \\
\hline Paris & 0.92 & 2 & 1.00 & 1 \\
\hline $\begin{array}{l}\text { Berlin } \\
\end{array}$ & 0.40 & 3 & & \\
\hline Brussels & 0.35 & 4 & & \\
\hline Rome & 0.26 & 5 & & \\
\hline Amsterdam & 0.26 & 6 & & \\
\hline Madrid & 0.26 & 7 & & \\
\hline Budapost & 0.22 & 8 & 0.21 & 4 \\
\hline Vienna & 0.18 & 9 & & \\
\hline Warsaw & 0.17 & 10 & 0.40 & 2 \\
\hline Athens & 0.14 & 11 & & \\
\hline Prague & 0.12 & 12 & 0.28 & 3 \\
\hline Lisbon & 0.12 & 13 & & \\
\hline Bucharest & 0.11 & 14 & 0.19 & 5 \\
\hline Copenhagen & 0.11 & 15 & & \\
\hline Riga & 0.10 & 16 & & \\
\hline Stockholm & 0.10 & 17 & & \\
\hline Dublin & 0.08 & 18 & & \\
\hline Soffia & 0.07 & 18 & 0.12 & 6 \\
\hline Helsinki & 0.06 & 20 & & \\
\hline Bratislava & 0.06 & 21 & & \\
\hline $\begin{array}{l}\text { Vilnius } \\
\end{array}$ & 0.04 & 22 & & \\
\hline Tallinn & 0.03 & 23 & & \\
\hline Lubjana & 0.02 & 24 & & \\
\hline Luxembourg & 0.02 & 25 & & \\
\hline $\begin{array}{l}\text { Valletta } \\
\end{array}$ & 0.01 & 26 & & \\
\hline $\begin{array}{l}\text { Nicosia } \\
\text { N }\end{array}$ & 0.01 & 27 & & \\
\hline \multicolumn{5}{|c|}{$\begin{array}{l}{ }^{1} \text { Relative integration potential of city / (see appendix for } \\
\text { this note and the following ones). } \\
{ }^{2} \text { Relative attractiveness of the five ECEEC cities in terms } \\
\text { of advanced services compared with that of Paris. }\end{array}$} \\
\hline
\end{tabular}

The five cities have relatively favorable interaction potentials. Even if their potentials are much less than those of the leading cities London and Paris, they reveal rather good positions (except for Sofia), more favorable than for many Western Europe capitals and in particular than for the Scandinavian ones. 

on the one hand the leading cities, Prague, Warsaw and Budapest; on the other hand, Bucharest and Sofia. Prague's heavy passenger traffic might be partly due to its tourist appeal.

Table 5. Air traffic.

\begin{tabular}{|c|c|c|c|c|}
\hline \multicolumn{5}{|c|}{ PASSENGERS TRAFFIC 2005} \\
\hline CITY & PASSENGERS $^{*}$ & $\%$ LONDON & $\%$ WORLD & $\%$ PRAGUE \\
\hline BUCHAREST & 3035511 & 2.26 & 0.075 & 28.16 \\
\hline BUDAPEST & 8049091 & 6.01 & 0.200 & 74.68 \\
\hline PRAGUE & 10777020 & 8.05 & 0.268 & 100.00 \\
\hline SOFIA & 1874367 & 1.40 & 0.046 & 17.39 \\
\hline WARSAW & 7071881 & 5.28 & 0.176 & 65.62 \\
\hline LONDON & 133857423 & 100.00 & & \\
\hline WORLD & 4009605158 & & 100.000 & \\
\hline
\end{tabular}

However, these data take their full meaning only when compared with air traffic in recognized global cities. Such a comparison shows that all five cities have very low air traffic. The busiest air traffic city in the world, London, had annual traffic of 133.8 million. In table 5, the traffic of the five ECEEC cities is expressed on the basis of 100 for London. The figures lie between 1.4 and 8.0 percent, much less than what could be 
expected on the basis on their population or even in view of their relative interaction potentials.

Another perspective is given by examples of European cities with approximately the same levels of passenger traffic. Prague ranks close to Lyon, Warsaw to Hanover or Toulouse, Budapest to Faro or Venice, Bucharest to Valencia or Strasbourg, Sofia to Milan or Santiago.

The global cities network rests essentially on international firms' interactions, which could be appraised through the simultaneous presence of the same advanced service firms in several cities. Thus, the world-wide connections of these firms allow us to evaluate the world insertion of a city.

The intensity of presence of 100 world leader firms in six categories of advanced services is reported in 316 cities (Taylor et alii, 2001). The degree of connectivity of a given city $A$ increases with the simultaneous presence, in a greater number of other cities, of the firms present in $A$, and with the intensity of this presence. London shows the highest connectivity in the world. Expressed as a percentage of this maximum, the connectivities of Budapest, Warsaw and Prague are comparable at a medium level (between 41.1 and 43.4), while the connectivities of Sofia and Bucharest are much lower (between 20.3 and 25.4). Some 213 cities have connectivities of less than 20 .

Thus, general data on air traffic volume reveal a dramatic lag between the ECEEC capitals and the major global cities in the rest of the world, as well as substantial inequalities between the five cities under study. Indeed, the evaluation of the world-wide connections through the presence of advanced services firms assigns a medium position to Budapest, Prague and Budapest as well as a low level of connectivity to Bucharest and Sofia.

\section{Contrasted globalization perspectives}

The two city globalization criteria, i.e. the presence of advanced services in the five cities and their insertion in a global network, converge toward the following evaluation of the five cities. Two groups clearly differ.

On the one hand, Prague, Warsaw and Budapest show signs of city globalization. It is noteworthy that while Warsaw dominates the five cities in terms of advanced services employment, Prague takes the first place if greater emphasis is placed on the presence of international firms in advanced services and on air traffic. Nevertheless, these two cities are in different situations.

Prague, specialized in hostelry and catering, seems to take advantage of its tourist appeal to promote a city globalization process. Prague exerts "pulling" power through its cultural character. The city attracts tourists and the attraction has positive repercussions on the representation of the city by economic decision-makers. Thus, Prague benefits from a good image which is an incentive to invest, to create or reinforce interactions. Indeed, the Czech capital occupies the 17th rank in an annual survey of the 30 leading European cities in terms of business attractiveness, ahead of Warsaw and Budapest (Cushman \& Wakefield Healey \& Baker, 2003).

57 Warsaw, despite shortcomings for certain economic criteria, appears in a good overall position to become a global city. Unlike Prague, Warsaw does not enjoy an initial cultural advantage, however the Polish capital is favored by its geographical position. Thus, 
Warsaw emerges as a gateway to the large Eastern market in the opinion of international investors. Moreover, the city seems to be more and more specialized in finance (Bourdeau-Lepage \& Huriot, 2002), which is at the core of business activities. domestic product (GDP) is just 26 and $23 \%$ of the average European per capita GDP (Europe of 15 in SPA 2000). In addition, the agriculture and the manufacturing sectors are still over-represented relative to the other transition countries (Bourdeau-Lepage, 2006). Consequently, local conditions play a major part in ECEEC city globalization. However, it seems that the employment structures of Bucharest and Sofia are closer to those of the average structure of the five cities than to the structure of their respective countries. In other words, despite their backwardness in terms of advanced services relative to the other three cities, they are far in advance relative to their own countries. If the capitals are able to pass on changes to their countries, the diagnosis may be slightly more optimistic.

art from these economic factors, the future differential development of these cities and their chances of emerging as global cities depend also on the interplay of historical, geographical and institutional factors. Factors such as the original historical development of the country and its influence on behaviors should also be included. The political dimension must not be overlooked. It determines the potential for city globalization, indirectly through the type and the stability of government, but also directly through regional and urban policies. Alongside strategies of private individual agents, public policies can be significant in promoting cities and creating attractive conditions. In particular, central or local government can invest in infrastructure, and thus create sufficient agglomeration economies to attract a number of firms which individually would have no incentive to locate there. However, it seems that urban policy is dramatically absent or largely ineffective in the five cities studied here.

In the context of European economic integration, the findings of this paper prompt an additional interpretation. A global city is a center of coordination of the global economy and it is connected to other cities at the highest level of economic activity, i.e. conception, decision and control of production and trade. Consequently, if the ECEEC capitals are well integrated in their countries, i.e. if they have sufficient economic interactions with their hinterlands and with their respective secondary cities, then their emerging global character may favor the economic integration of their countries in the world, and especially in Europe. Under these circumstances, inequalities in terms of city 
globalization may well turn into serious inequalities in terms of the capacity of the corresponding countries to really integrate the European Union rapidly.

\section{BIBLIOGRAPHY}

AIRPORT COUNCIL INTERNATIONAL (2003), Report January 2003, data non-available.

ANGOTTI T. (1993), Metropolis 2000- Planning. Powerty and Politics, London, Routledge.

AREA METROPOLITANA DE LISBOA (2003), Informação estatistica da AML, www.aml.pt.

BEAVERSTOCK J.V. SMITH R.G. \& TAYLOR P.J. (1999), “A Roster of World Cities”, Cities, 16, 6, pp. 445-458.

BEHRENS A. (2003), "Produit Intérieur Brut régional des pays candidats 2000", Bruxelles, in EUROSTAT, Statistiques en bref, table 2, www.europa.gov.eu.

BEHRENS K. (2003), Structure of Trade and Agglomeration: How Impediments to Trade Shape the Spaceeconomy, PhD, Dijon, Université de Bourgogne.

BOURDEAU-LEPAGE L. (2002), "Varsovie entre agglomération et dispersion”, Revue d'Economie Régionale et Urbaine, 5, pp. 805-829.

BOURDEAU-LEPAGE L. (2004), “Varsovie, une nouvelle métropole”, GaWC Research Bulletin 142(A), Loughborough University: Global and World Cities Study Group and Network, www.lboro.ac.uk/ gawc.

BOURDEAU-LEPAGE L. (2006), "Advanced Services and Regional Integration. The Potential of Regions in East Central and Eastern European Countries", Die Erde, 1, Berlin.

BOURDEAU-LEPAGE L. \& HURIOT J.-M. (2002), "Metropolization in Warsaw. Economic Change and Urban Growth", Canadian Journal of Regional Science, XXV, 3, pp. 423-446.

BOURDEAU-LEPAGE L. \& HURIOT J.M. (2005a), "La métropolisation, thème et variations", in BUISSON M.A. \& MIGNOT D. (Eds), Concentration économique et ségrégation spatiale, Bruxelles, De Boeck Université, pp. 39-65.

BOURDEAU-LEPAGE L. \& HURIOT J. M. (2005b), “The metropolis in retrospect. From the Trading Metropolis to the Global Metropolis", Louvain Economic Review, 71, 3, pp. 257-284.

BOURDEAU-LEPAGE L. \& HURIOT J.-M. (2006), "Megacities vs. Global Cities. The institutional hypothesis", Document de travail série économie, 2006-05, Dijon, LEG.

BULGARIAN CENTRAL STATISTICAL OFFICE (2003), Employees by branches, Sofia, Bulstat.

CASTELLS M. (1996), The Rise of the Network Society, Oxford, Blackwell.

CUSHMAN \& WAKEFIELD HEALEY \& BAKER (2003), European Cities Monitor 2003, London, Healey \& Baker, Marketing Department.

CZECH OFFICE FOR SURVEYING (2003a), Mapping and Cadastre and Indicators of Social and Economic Development of the Czech Republic 1990 - $4^{\text {th }}$ quarter 2002, Prague, CSO.

CZECH STATISTICAL OFFICE (2003b), Labour Force Survey, Prague, CSO. 
DOGAN M. (2004), "Four hundred giant cities atop the world", International Social Science Journal, 56, (181), pp. 347-360.

EUROSTAT (2003), Economic Accounts. ESA95, Brussels, REGIO.

FRIEDMAN J. (1986), “The world city hypothesis”, Development and Change, 17, pp. 69-83.

FUJITA M. \& THISSE J.F. (2002), Economics of Agglomeration. Cities, Industrial Location and Regional Growth, Cambridge, Cambridge University Press.

GEHRIG T. (2000), "Cities and the Geography of Financial Centers", in HURIOT J.-M. \& THISSE J.-F. (Eds.) (2000), Economics of Cities. Theoretical perspectives, Cambridge, Cambridge University Press, pp. 415-445.

GUS CENTRAL STATISTICAL OFFICE (2002), Powiaty $w$ Polsce 2001, Warsaw, GUS.

HALL P. (1966), The World Cities, London, Weidenfeld and Nicolson.

HOHENBERG P.M. \& LEES L.H. (1995), The Making of Urban Europe, 1000-1994, Cambridge, Harvard University Press.

HOOVER E. \& VERNON R. (1962), Anatomy of a metropolis, New York, Anchor Books.

HURIOT J.-M. \& PERREUR J. (1997), “Centre et périphéries: fondements et critères”, in CÉLIMÈNE F. \& LACOUR C. (Eds), L'intégration régionale des espaces, Paris, Economica, pp. 63-84.

HURIOT J.-M. \& THISSE J.-F. (Eds.) (2000), Economics of Cities. Theoretical perspectives, Cambridge, Cambridge University Press.

INSSE (2003), Yearbook 2001, www.insse.ro.

KNOX P.L. \& TAYLOR P.J. (Eds.) (1995), World Cities in a World Economic System, Cambridge, Cambridge Press University.

KRUGMAN P. (1996), The Self-Organizing Economy, Cambridge, Blackwell.

KSHBPMI (Central Statistical Office Budapest and Pest Country Directory) (2002), Budapest statistikai Evkonyve 2001 (Statistical Yearbook of Budapest), Budapest.

LACOUR C. \& PUISSANT S. (Eds.) (1999), La métropolisation. Croissance, Diversité, Fracture, Paris, Anthropos Collection Villes.

MUNICIPALITY OF SOFIA. (2003), Labour Market, Culture and Art, Tourism, Education, www.sofia.bg. NORTH D.C. (1990), Institutions, Institutional Change and Economic Performance, Cambridge, Cambridge University Press.

REED H.C. (1991), The Pre-eminence of International Financial Centers, New York, Praeger.

SASSEN S. (2001), The Global City: New-York. London. Tokyo, Princeton, Princeton University Press.

SASSEN S. (2002), "Locating Cities on Global Circuits”, in SASSEN S. (Ed.), Global Networks, Linked Cities, New York, London, Routledge, pp. 1-36.

SYKORA L. (1995), "Metropolises in Transition, Metropolises in Competition: Globalization of Central European Cities and their Integration into European Urban Network", in European Conference Proceedings, Urban Utopias: New Tools for the Renaissance of the City in Europe, CD-ROM, Berlin, TVVF.

TAYLOR P.J., CATALANO G. \& WALKER D.R.F (2001), "Measurement of the World City Network", GaWC Research Bulletin 43 (Z), Loughborough University, Global and World Cities Study Group and Network, www.lboro.ac.uk/gawc. 
TAYLOR P.J. (2003), "Regionality in the World City Network", GaWC Research Bulletin, 116 (Z), Loughborough University, Global and World Cities Study Group and Network, www.lboro.ac.uk/gawc.

USW (STATISTICAL OFFICE IN WARSAW) (1996), Rocznik Statystyczny Warszawy 1996 (Yearbook of Warsaw 1996), Warszawa, USW.

USW (STATISTICAL OFFICE IN WARSAW) (2003), Panorama gmin Warszawy 2001 rok, Warsaw, USW.

\section{APPENDIXES}

\section{METHODOLOGICAL NOTE}

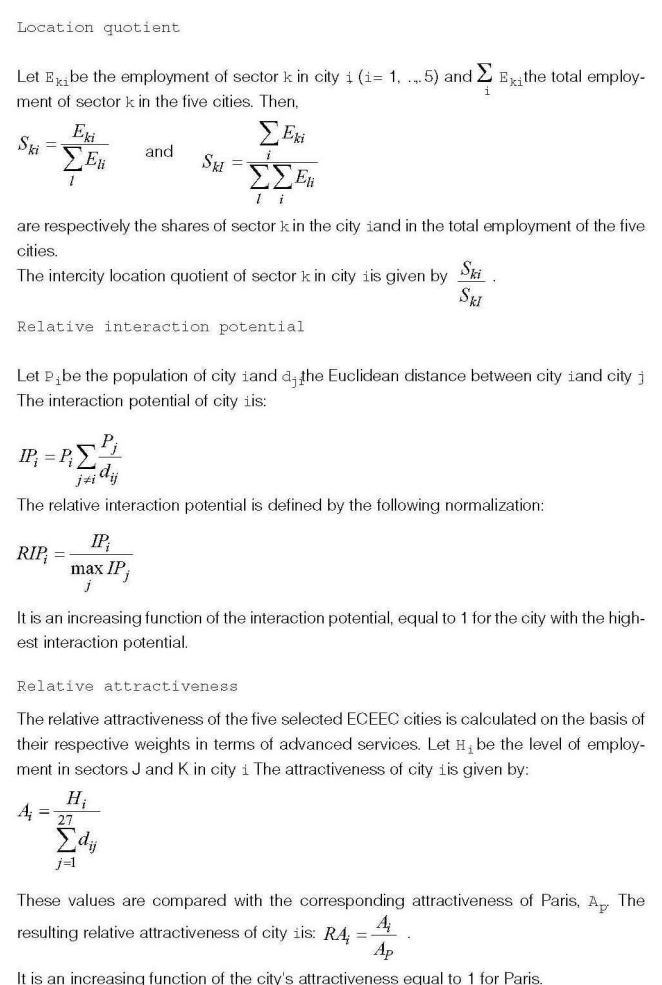

\section{ABSTRACTS}

Capital cities in East Central and Eastern European Countries (ECEEC) are changing rapidly. Since the 1990s, the ECEEC capitals have faced the double challenge of the market (the transition process) and of integration in the world economy (the globalization process), which supposes a sufficient development of coordination functions and thus of advanced services concentrated in these cities (city globalization). Their capacity to join the network of global cities is evaluated on the basis of their relative specializations in advanced services and their connections with the rest of the world.

The comparative analysis leads to contrasted globalization perspectives. Thus, Budapest, Prague and Warsaw show signs of city globalization while Bucharest and Sofia are hampered by historical, geographical and institutional factors.

Avec la transition, les grandes villes d'Europe centrale et orientale sont face au défi de la globalisation urbaine et de l'économie post-industrielle. Dans ce contexte, l'article évalue la 
capacité de Bucarest, Budapest, Prague, Sofia et Varsovie à s'insérer dans le réseau des grandes villes européennes. Pour cela, deux séries de critères d'identification d'une ville globale sont utilisés: la concentration de services supérieurs et l'étude des relations extérieures qui permettent d'évaluer la puissance économique potentielle et le degré de rayonnement des villes. Deux types de développement urbain sont mis en évidence. Budapest, Prague et Varsovie sont dans une position beaucoup plus favorable sur la voie de la globalisation que Bucarest et Sofia. La globalisation urbaine des capitales des PECO semble soumise à deux types de forces: une force globale, celle de l'économie post-industrielle, et une force locale (effet-pays) liée aux spécificités nationales.

INDEX

Mots-clés: Bucarest, Budapest, capitales, Europe centrale et orientale, globalisation urbaine, Prague, services supérieurs, Sofia, Varsovie

Keywords: advanced services, Bucharest, Budapest, capital cities, city globalization, East Central and Eastern European countries, Prague, Sofia, Warsaw

\section{AUTHOR}

\section{LISE BOURDEAU-LEPAGE}

Université de Bourgogne, LEG-CNRS-MSH, PEG, BP 26 611, 21066 Dijon cedex - France, lbourd@u-bourgogne.fr 